\title{
PENGARUH SUHU PEMANASAN PADA EKSTRAK TEH (C. sinensis Linn.) JENIS TEH PUTIH TERHADAP STABILITAS SIFAT ANTIOKSIDATIFNYA
}

\author{
The Effect of Thermal Treatment on Tea (C. sinensis Linn.) Extract, Type of White \\ Tea on the Stability of Its Antioxidant Activity \\ Rohadi dan Sri Budi Wahjuningsih \\ Program Studi Teknologi Hasil Pertanian Fakultas Teknologi Pertanian Universitas Semarang \\ email: rohadijarod_ftp@usm.ac.id
}

\begin{abstract}
The thermal process is able to improve the nutrition and antioxidant activity of coriander leaves. However, the high temperature thermal process $\left(>120^{\circ} \mathrm{C}\right)$ can damage and reduce the antioxidant activity. The aim of the study was to analyze the effect of oven heating temperature on the antioxidant stability of aqueous white tea extract (ETP). The extract was concentrated with a rotary vacuum evaporator and dried freeze with a freeze dryer. ETP was heat treated in oven $(30,80,90,100$, 110 and $120^{\circ} \mathrm{C} / 3$ minutes) and ETP was assay, for antioxidant activity: total phenolic, total flavonoids, DPPH free radical scavenging assay and total reduction, at various concentrations (50-250 ppm). The results showed that there were significant differences in the effect of heating on the assay of total phenolic, total flavonoids, free radical scavenging activity, total reduction and $I C_{50}$ at all concentrations $(p<0.05)$. DPPH free radical scavenging activity assay at ETP $50 \mathrm{ppm}$ increased from $5.25 \pm 1.0 \%\left(30^{\circ} \mathrm{C}\right)$ to $29.15 \pm 0.13\left(120^{\circ} \mathrm{C}\right)$, ETP $250 \mathrm{ppm}$ rose from $42.78 \pm 2.4 \%\left(30^{\circ} \mathrm{C}\right)$ to $58.21 \pm 0.13 \%\left(120^{\circ} \mathrm{C}\right)$. The total ferric ion reduction assay (OD value) increased from $0.046\left(50 \mathrm{ppm} / 30^{\circ} \mathrm{C}\right)$ to $0.091\left(50 \mathrm{ppm} / 120^{\circ} \mathrm{C}\right)$ to $0.28\left(250 \mathrm{ppm} / 30^{\circ} \mathrm{C}\right)$ to $0.662\left(250 \mathrm{ppm} / 120^{\circ} \mathrm{C}\right)$. The $I C_{50}$ ETP value increased from $320 \mathrm{ppm}\left(30^{\circ} \mathrm{C}\right)$ $182.5 \mathrm{ppm}\left(120^{\circ} \mathrm{C}\right)$.
\end{abstract}

Keywords: thermal process, white tea extract, $I C_{50}$; antioxidant activity

\begin{abstract}
Abstrak Proses termal mampu memperbaiki nutrisi dan aktivitas antioksidan daun ketumbar (Coriandrum sativum L.). Namun proses termal suhu tinggi $\left(>120^{\circ} \mathrm{C}\right.$ ) dapat merusak senyawa bioaktif dan menurunkan aktivitas antioksidan. Tujuan penelitian adalah melakukan analisis pengaruh suhu pemanasan oven terhadap stabilitas antioksidatif aqueous ekstrak teh putih (ETP). Ekstrak dipekatkan dengan a rotary vacuum evaporator dan dikering bekukan dengan freeze dryer. ETP dipanaskan dengan microwave-oven (30, 80, 90, 100, 110 dan $120^{\circ} \mathrm{C} / 3$ menit) dan ETP diuji aktivitas antioksidan: total fenolik, flavonoid, uji penangkapan radikal bebas $D P P H$, dan total reduksi pada berbagai konsentrasi (50-250 ppm). Hasil penelitian menunjukan ada perbedaan signifikan pengaruh pemanasan terhadap uji total fenolik, total flavonoid, aktivitas penangkapan radikal bebas, total reduksi, dan $I C_{50}$ pada semua konsentrasi $(p<0,05)$. Uji aktivitas penangkapan radikal bebas DPPH pada ETP 50 ppm naik dari $5,25 \pm 1,0 \%\left(30^{\circ} \mathrm{C}\right)$ menjadi $29,15 \pm 0,13 \%\left(120^{\circ} \mathrm{C}\right)$, ETP 250 ppm naik dari 42,78 $2,4 \%\left(30^{\circ} \mathrm{C}\right)$ menjadi $58,21 \pm 0,13 \%\left(120^{\circ} \mathrm{C}\right)$. Pada uji total reduksi ion feri (nilai OD) meningkat dari 0,046 $\left(50 \mathrm{ppm} / 30^{\circ} \mathrm{C}\right)$ menjadi 0,091 $\left(50 \mathrm{ppm} / 120^{\circ} \mathrm{C}\right)$ hingga $0,28\left(250 \mathrm{ppm} / 30^{\circ} \mathrm{C}\right)$ menjadi 0,662 $\left(250 \mathrm{ppm} / 120^{\circ} \mathrm{C}\right)$. Nilai I $\mathrm{C}_{50}$ ETP meningkat dari $320 \mathrm{ppm}\left(30^{\circ} \mathrm{C}\right)-182,5 \mathrm{ppm}\left(120^{\circ} \mathrm{C}\right)$.
\end{abstract}

Kata kunci: Proses termal, ekstrak teh putih, $\mathrm{IC}_{50}$; aktivitas antioksidan

\section{PENDAHULUAN}

Proses termal lazim diaplikasikan pada proses pengolahan pangan untuk berbagai tujuan antara lain inaktivasi enzim, perbaikan warna dan tekstur, perbaikan mutu nutrisi, dan sterilisasi spora dan bakteri pathogen (Dewanto et al., 2002; Li-Yuan Zhou et al., 2017). Blanching, pemanggangan (roasting), perebusan (boiling), oven gelombang mikro (microwaving), dan sterilisasi adalah beberapa contoh aplikasi proses termal (Micali dan Fiorino, 2016; Li-Yuan Zhou et al., 2017). Efektivitas proses termal sangat dipengaruhi oleh intensitas panas, suhu dan lama pemanasan serta perbedaan metode pemasakan (Li-Yuan Zhou et al., 2017). Proses termal mampu memperbaiki 
nutrisi dan aktivitas antioksidan buah tomat (Dewanto et al., 2002). Namun proses termal pada suhu tinggi $\left(>180^{\circ} \mathrm{C}\right)$ dapat merusak dan menurunkan kapasitas antioksidatif suatu antioksidan (Reda, 2011).

Penggunaan antioksidan alami (natural antioxidant) untuk pencegahan rusak pangan oleh oksidasi memperoleh banyak perhatian peneliti (Mielnik et al., 2006; Vayupharap dan Laksanalamal, 2011; Rai et al., 2012; Rohadi et al., 2016; Rohadi dan Wahjuningsih, 2018). Ekstrak aqueous teh putih (ETP) mengandung total fenolik $18,56 \pm 0,25 \%$ (g-GAE/100 g) dan 4,28 $\pm 0,1 \%$ (g-QE/100 g) dan bersifat menangkap radikal bebas DPPH dan mereduksi ion $\mathrm{Fe}^{3+}$, meski tidak sekuat BHA dan ekstrak biji anggur (Rohadi dan Wahjuningsih, 2018). Lelita et al., (2018) mengatakan aktivitas antioksidatif RSA-DPPH ETP relatif lebih tinggi yakni $92,91 \pm 0,08 \%$, dibanding jenis teh lain, teh Oolong $87,20 \pm 0,217 \%$, teh hijau (green tea), $86,32 \pm 0,10 \%$ dan teh hitam (black tea) 55,48 $\pm 0,68 \%$ (1000 ppm) (Lelita, 2018). Setyopratomo (2014) mengatakan ekstrak etanol $20 \%$ teh putih pada berbagai suhu ekstraksi $\left(40-60^{\circ} \mathrm{C}\right)$ mengandung total fenolik 21-25\% (g-GAE/100-g). Senyawa bioaktif utama yang terdapat pada ekstrak teh putih antara lain katekin (C), epikatekin (EC), epigalokatekin (EGC), epikatekin galat (ECG) dan epigalokatekin-3-galat (EGCG) (Rai et al., 2012).

Perlakuan panas (autoclave) terhadap ekstrak biji anggur $\left(100^{\circ} \mathrm{C} / 0-60\right.$ menit) menyebabkan hidrolisis galokatekin $(70 \%)$, katekin (61\%), epikatekin (65\%), prosianidin B1 $(75 \%)$, dan prosianidin B2 (73\%), mampu meningkatkan konsentrasi asam galat (71\%), galokatekin $(100 \%)$ dan epikatekin galat $(129 \%)$ pada grape pomace, namun tidak berpengaruh nyata terhadap aktivitas antioksidannya (Chamorro et al., 2012). Perlakuan panas terhadap daun ketumbar baik dengan microwave (100-900 watt/960290 detik) maupun oven $\left(40-120^{\circ} \mathrm{C} / 264-\right.$ 48 menit) mampu meningkatkan nilai total fenolik, total flavonoid, uji penangkapan radikal bebas DPPH dan ABTS pada suhu $40-80{ }^{\circ} \mathrm{C}$, namun menurunkan nilai total fenolik, total flavonoid, uji penangkapan radikal bebas DPPH dan ABTS pada suhu 100-120 ${ }^{\circ} \mathrm{C}$ (Hihat et al., 2017).

Antioksidan bersifat sensitif terhadap proses termal dan pemasakan suhu tinggi dapat menurunkan sifat antioksidatifnya serta merusak struktur kimia senyawa penyusunnya (Reda, 2011; Chamorro et al., 2012; Hihat et al., 2017). Diperlukan kajian pengaruh proses termal terhadap stabilitas antioksidan sebelum diaplikasikan pada proses pangan. Penelitian ini bertujuan menganalisis pengaruh suhu pemanasan oven terhadap stabilitas antioksidatif ETP dan umpan balik pemanfaatan ETP sebagai antioksidan pada proses pangan.

\section{METODOLOGI}

Bahan teh putih Kaligua, Produksi PT. Perkebunan Nusantara IX sebanyak 250 gram, Bahan kimia meliputi: asam galat hidrat, asam askorbat (Sigma Chemical Co. St. Louis USA), quercetin (Waco Pure Chemical Industry-Osaka Japan), butylated hydroxyanisole -BHA (Sigma Chemical Co.), asam hidroklorida ( $\mathrm{HCl})$, fero klorida $\left(\mathrm{FeCl}_{2}\right)$, feri klorida $\left(\mathrm{FeCl}_{3}\right)$, amonium tiosianat, $\mathrm{K}_{3} \mathrm{Fe}(\mathrm{CN})_{6}$, trychloroacetic acid (TCA), asam tungsto-fosforik 2,2-diphenyl1-picrylhydracyl radical (DPPH) (Aldrich Chemical Co.), kertas saring Whatman No.4 (Whatman International, Ltd. England), Folin-Ciocalteu reagent dan buffer phosphate $\mathrm{pH} 7$. Reagen kimia dan standar yang digunakan dalam kategori pro-analisis (kemurnian 95-98\%). Peralatan laboratorium yang dipakai adalah timbangan analitik Shimadzu AUW 120 (Shimadzu, Kyoto Japan), a rotary vacuum evaporator (IKA-RV 10 Basic), freeze dryer (Virtis SP Scientific Sentry 2.0), oven, vortex (Velp Scientifica Europe), water-bath shaker (Julabo SW 22) dan UV-Visible spectrophotometer (UV1601 Shimadzu, Japan).

Sebanyak 150 gram teh putih diekstrak dengan $500 \mathrm{~mL}$ aquades (1:10) sesuai metode Vasi dan Austin (2009) dengan modifikasi $\left(10\right.$ menit $/ 60 \pm 2{ }^{\circ} \mathrm{C}$ ) dengan teknik maserasi. Campuran difiltrasi dengan kertas 
saring Whatman, sehingga diperoleh ekstrak. Ekstrak dipekatkan dengan a rotary vacuum evaporator (IKA-RV 10 Basic) dan diperoleh cairan kental. Cairan kental dikering bekukan dengan freeze dryer (Virtis SP Scientific Sentry 2.0). Sisa pelarut dihilangkan dengan penyemprotan gas nitrogen $\left(\mathrm{N}_{2}\right)$, sehingga diperoleh ekstrak kering teh putih (ETP) dan dihitung yield. ETP dilakukan pemanasan oven pada berbagai suhu (30, $80,90,100,110$ dan $120^{\circ} \mathrm{C}$ ) selama 3 menit untuk selanjutnya selanjutnya dilakukan uji aktivitas antioksidan: total fenolik dan total flavonoid (Ebrahimzadeh et al., 2008), uji penangkapan radikal bebas DPPH (radical scavenging activity-RSA-DPPH) menurut Vasi dan Austin (2009), total reduksi ion feri (ferric reducing antioxidant power) menurut Vasi dan Austin (2009), pada berbagai konsentrasi (50, 100, 150, 200 dan 250 ppm). Rancangan penelitian berupa rancangan acak kelompok (RAK) dengan satu faktor (suhu pemanasan) dengan 6 perlakuan. Variabel diamati meliputi uji total fenolik, flavonoid, DPPH dan FRAP. Nilai rata-rata dianalisis varian (Anova) untuk melihat ada/tidak perbedaan antar perlakuan, jika terdapat perbedaan nyata antar perlakuan dilakukan uji lanjut Duncan dengan program SAS 9.2. Data disajikan sebagai rata-rata \pm standar deviasi (SD).

\section{HASIL DAN PEMBAHASAN}

\section{Hasil analisis proksimat teh Putih}

Sebanyak 150 gram Teh Putih Kaligua yang dibeli langsung dari pabrik teh yang berlokasi di Kaligua dalam keadaan baik. Kondisitehberkadarair 8,86 $\pm 0,19 \%$ (Tabel 1), sedikit di atas SNI 3836:2013 tentang produk teh yang mensyaratkan kadar air maksimum $8 \%$. Hal ini dimungkinkan karena perbedaan batch dan tanggal produksi sampel. Penelitian sebelumnya disebutkan kadar air teh Putih Kaligua 7,44 $\pm 0,064 \%$ (Rohadi dan Wahjuningsih, 2018). Sedangkan kadar abu 4,60 $\pm 0,004 \%$, memenuhi standar SNI ditetapkan maksimal 8\%. Hasil ekstraksi diperoleh hasil (yield) $8,77 \pm 1,1 \%$. Nilai yield ekstraksi teh putih dengan pelarut $n$-heksan, etil asetat dan etanol $96 \%$ berturut-turut $0,62 \pm 0,04 \%, 1,82 \pm 0,27 \%$ dan $9,42 \pm 1,88 \%$ (Widyasanti et al., 2016). Penelitian sebelumnya disebutkan yield jenis teh yang sama sebesar $14,42 \pm 1,66 \%$ (Rohadi dan Wahjuningsih, 2018). Perbedaan nilai yield rendemen tersebut disebabkan antara lain oleh perbedaan jenis teh dan polaritas pelarut, serta metode ekstraksi (Martin et al., 2011; Tram et al., 2015).

Tabel 1. Hasil analisis proksimat teh putih

\begin{tabular}{clc}
\hline No. & Komponen & Kadar (\%) \\
\hline 1 & Air & $8,86 \pm 0,19$ \\
2 & Protein & $10,44 \pm 0,35$ \\
3 & Lipid & $0,76 \pm 0,01$ \\
4 & Serat kasar & $1,27 \pm 0,35$ \\
5 & Karbohidrat total & $75,23 \pm 0,02$ \\
6 & Abu & $4,60 \pm 0,004$ \\
\hline & & $\mathrm{n}=2$ (duplo)
\end{tabular}

\section{Hasil analisis total fenolik}

Hasil analisis total fenolik ETP pada berbagai suhu pemanasan disajikan pada Tabel 2. Suhu pemanasan berpengaruh sangat nyata terhadap uji total fenolik ETP $(p<0,05)$. Peningkatan suhu pemanasan pada oven $\left(30-120^{\circ} \mathrm{C} / 3\right.$ menit) pada semua konsentrasi ETP mampu meningkatan total fenolik. Wu et al., (2013) mengatakan sangrai (roasting) $\left(150^{\circ} \mathrm{C} / 60\right.$ menit) pada pembuatan teh sorghum (sorghum tea) secara signifikan mampu meningkatkan kadar asam fenolik, total fenolik, total flavonoid dan procyanidin (PAC) dibanding proses perendaman dan pengukusan (steaming). Perlakuan panas ( $88^{\circ} \mathrm{C} / 2-30$ menit) diketahui mampu mampu meningkatkan aktivitas antioksidan pada buah tomat $5,29 \pm 0,26-6,70 \pm 0,25 \mu \mathrm{mol}$ vitamin $\mathrm{C}$ ekuivalen/g buah Tomat). Namun tidak secara nyata meningkatkan baik total fenolik maupun total flavonoid (Dewanto et al., 2002).

Proses termal (dry thermal) dapat meningkatkan atau menurunkan hasil uji senyawa fenolik (tidak selalu korelatif dengan nilai aktualnya) dan berhubungan dengan 
sifat antioksidatif senyawa fenolik (Wu et al., 2013; Taylor dan Duodu, 2019). Namun demikian mekanisme sangat kompleks melalui berbagai kemungkinan yakni oksidasi, degradasi panas, depolimerisasi menjadi senyawa fenolik sederhana, pembentukan senyawa kompleks dengan polimer lain dan pelepasan asam fenolik serta produksi berbagai senyawa melalui reaksi Maillard (Taylor dan Duodu, 2019). Chamorro et al., (2012) menyatakan adanya peningkatan konsentrasi senyawa bioaktif pada ekstrak biji anggur yang dipanaskan dengan autoclave melalui mekanisme hidrolisis senyawa polimer.
Teh putih kaya senyawa polifenolik baik dalam bentuk polimer seperti tanin kompleks dan tanin terkondensasi, oligomer seperti proanthocyanidin, bisflavanol, dan theaflavin hingga yang bentuk monomer seperti anthocyanidin, katekin (flavanol) dan asam fenolik (Khanbabaee dan Teunis van Ree, 2001; Hilal dan Engelhardt, 2007; Zhang dan Lin, 2009). Selama proses pengolahan baik dengan proses termal maupun kimia (hidrolisis asam) dimungkinkan senyawa polimer atau oligomer terhidrolisis menjadi senyawa-senyawa yang lebih sederhana dan hal ini diduga kuat, kontributif terhadap sifat antioksidatifnya.

Tabel 2. Hasil analisis total fenolik ETP pada berbagai suhu (mg-GAE/100 g)

\begin{tabular}{ccccccc}
\hline \multirow{2}{*}{ [ppm] $]$} & \multicolumn{7}{c}{ Suhu pemanasan $\left({ }^{\circ} \mathbf{C}\right)$} \\
\cline { 2 - 7 } & $\mathbf{3 0}$ & $\mathbf{8 0}$ & $\mathbf{9 0}$ & $\mathbf{1 0 0}$ & $\mathbf{1 1 0}$ & $\mathbf{1 2 0}$ \\
\hline 50 & $7,9 \pm 1,0^{\mathrm{a}}$ & $11,3 \pm 1,0^{\mathrm{b}}$ & $14, \pm 0,10^{\mathrm{c}}$ & $16,6 \pm 0,5^{\mathrm{d}}$ & $20,2 \pm 0,5^{\mathrm{e}}$ & $23,2 \pm 0,5^{\mathrm{f}}$ \\
100 & $9,1 \pm 1,4^{\mathrm{d}}$ & $13,3 \pm 3,7^{\mathrm{cb}}$ & $12,6 \pm 0,4^{\mathrm{c}}$ & $14,0 \pm 0,5^{\mathrm{cb}}$ & $15,8 \pm 0,25^{\mathrm{ab}}$ & $18,1 \pm 0,3^{\mathrm{a}}$ \\
150 & $10,0 \pm 1,0^{\mathrm{e}}$ & $13,1 \pm 0,3^{\mathrm{d}}$ & $15,0 \pm 0,1^{\mathrm{c}}$ & $16,0 \pm 0,01^{\mathrm{b}}$ & $16,9 \pm 0,06^{\mathrm{a}}$ & $17,6 \pm 0,01^{\mathrm{a}}$ \\
200 & $11,0 \pm 1,8^{\mathrm{d}}$ & $13,2 \pm 2,0^{\mathrm{c}}$ & $14,0 \pm 0,2^{\mathrm{cb}}$ & $14,6 \pm 2,9^{\mathrm{cb}}$ & $15,0 \pm 0,15^{\mathrm{b}}$ & $16,8 \pm 0,26^{\mathrm{a}}$ \\
250 & $14,1 \pm 0,3^{\mathrm{b}}$ & $14,7 \pm 0,1^{\mathrm{b}}$ & $15,4 \pm 0.1^{\mathrm{ab}}$ & $16,1 \pm 0,15^{\mathrm{ab}}$ & $16,6 \pm 1,5^{\mathrm{ab}}$ & $17,6 \pm 0,15^{\mathrm{a}}$ \\
\hline
\end{tabular}

Keterangan: Huruf superskrip yang berbeda pada baris yang sama menunjukkan ada perbedaan nyata antar perlakuan $(p<0,05), \mathrm{n}=3$.

\section{Hasil analisis total flavonoid}

Hasil analisis total flavonoid ETP pada berbagai suhu pemanasan disajikan pada Tabel 3. Suhu pemanasan berpengaruh sangat nyata terhadap uji total flavonid ETP $(p<0,05)$. Peningkatan suhu pemanasan pada oven $\left(30-120^{\circ} \mathrm{C} / 3\right.$ menit) pada semua konsentrasi ETP mampu meningkatkan total flavonoid.

Tabel 3. Hasil analisis total flavonid ETP pada berbagai suhu (mg-QE/100 g)

\begin{tabular}{ccccccc}
\hline \multirow{2}{*}[\mathrm{cpm}]{} & \multicolumn{6}{c}{ Suhu Pemanasan $\left({ }^{\circ} \mathrm{C}\right)$} \\
\cline { 2 - 7 } & 30 & 80 & 90 & 100 & 110 & 120 \\
\hline 50 & $2,02 \pm 0,60^{\mathrm{e}}$ & $5,9 \pm 0,29^{\mathrm{ed}}$ & $8,56 \pm 1,5^{\mathrm{d}}$ & $18,2 \pm 2,3^{\mathrm{c}}$ & $24,6 \pm 3,7^{\mathrm{b}}$ & $38,35 \pm 2,6^{\mathrm{a}}$ \\
100 & $5,71 \pm 1,1^{\mathrm{f}}$ & $12,05 \pm 1,6^{\mathrm{e}}$ & $13,53 \pm 0,8^{\mathrm{d}}$ & $14,26 \pm 1,1^{\mathrm{c}}$ & $18,8 \pm 0,5^{\mathrm{b}}$ & $26,1 \pm 1,1^{\mathrm{a}}$ \\
150 & $7,90 \pm 1,2^{\mathrm{e}}$ & $11,64 \pm 0,7^{\mathrm{d}}$ & $12,63 \pm 1,8^{\mathrm{cd}}$ & $13,78 \pm 0,7^{\mathrm{bc}}$ & $15,09 \pm 0,7^{\mathrm{b}}$ & $21,16 \pm 0,5^{\mathrm{a}}$ \\
200 & $8,57 \pm 0,6^{\mathrm{f}}$ & $10,32 \pm 0,4^{\mathrm{e}}$ & $12,92 \pm 0,3^{\mathrm{d}}$ & $14,02 \pm 0,4^{\mathrm{c}}$ & $15,25 \pm 0,5^{\mathrm{b}}$ & $18,32 \pm 0,6^{\mathrm{a}}$ \\
250 & $9,2 \pm 1,0^{\mathrm{d}}$ & $11,61 \pm 1,4^{\mathrm{c}}$ & $12,00 \pm 0,3^{\mathrm{c}}$ & $13,08 \pm 0,8^{\mathrm{c}}$ & $15,45 \pm 0,4^{\mathrm{b}}$ & $17,12 \pm 0,8^{\mathrm{a}}$ \\
\hline
\end{tabular}

Keterangan: Huruf superskrip yang berbeda pada baris yang sama menunjukkan ada perbedaan nyata antar perlakuan $(p<0,05), \mathrm{n}=3$. 
Perlakuan panas (thermal treatment) pada ekstrak biji anggur dengan autoclave diketahui menyebabkan hidrolisis galokatekin, katekin, epikatekin, prosianidin B1, dan prosianidin B2 pada berbagai tingkat. Proses yang sama pada grape pomace mampu meningkatkan konsentrasi asam galat $(71 \%)$, galokatekin $(100 \%)$ dan epikatekin galat (129\%). Namun demikian perlakuan panas dengan oven, tidak menyebabkan perubahan yang nyata pada hasil uji total fenolik, total tanin, prosianidin dan aktivitas antioksidan (Chamorro et al., 2012). Wu et al. (2013) mengatakan sangrai (roasting) $\left(150^{\circ} \mathrm{C} / 60\right.$ menit) pada biji sorghum proses pembuatan teh sorghum (sorghum tea) secara signifikan mampu meningkatan kadar asam fenolik, total fenolik, total flavonoid dan procyanidin (PAC) serta korelatif dengan uji penangkapan radikal bebas DPPH (RSA-DPPH). Roasting dapat meningkatkan secara signifikan baik total fenolik $17 \%$ dan total asam fenolik $208 \%$, namun menurunkan total flavonoid $68 \%$ pada proses sangrai "finger millets" (Eleusine coracana). Namun sangrai dengan metode yang sama justru menurunkan $13 \%$ uji total fenolik, namun menaikan baik pada total flavonoid $70 \%$ dan asam fenolik total $208 \%$ pada proses sangrai milet jenis "pearl millets" (Pennisatum glaucum) (Hithamani dan Srinivasan, 2014; Yoshida dan Takagi, 1997).

Senyawa polifenol baik dalam bentuk polimer seperti tanin kompleks dan tanin terkondensasi, oligomer seperti proanthocyanidin, bisflavanol, dan theaflavin terdapat pada teh putih (Khanbabaee dan Teunis van Ree, 2001; Hilal dan Engelhardt, 2007; Zhang dan Lin, 2009). Selama pemanasanETPdengan oven, dimungkinkan senyawa polimer atau oligomer tersebut terhidrolisis menjadi senyawa yang lebih sederhana. Hal ini diduga kuat kontributif terhadap sifat antioksidatifnya. Pada roasting mekanisme peningkatan atau penurunannya sangat kompleks melalui berbagai kemungkinan yakni oksidasi, degradasi panas, depolimerisasi menjadi senyawa fenolik sederhana, pembentukan senyawa kompleks dengan polimer lain dan pelepasan asam fenolik serta produksi berbagai senyawa melalui reaksi Maillard (Taylor dan Duodu, 2019).

\section{Hasil analisis RSA-DPPH}

Hasil analisis aktivitas penangkapan radikal bebas DPPH (RSA-DPPH) ETP pada berbagai suhu pemanasan disajikan pada Tabel 4.

Tabel 4. Hasil analisis RSA-DPPH ETP pada berbagai suhu (\%)

\begin{tabular}{ccccccc}
\hline \multirow{2}{*}{ [Kons.] } & \multicolumn{6}{c}{ Suhu Pemanasan $\left({ }^{\circ} \mathrm{C}\right)$} \\
\cline { 2 - 7 } & 30 & 80 & 90 & 100 & 110 & 120 \\
\hline $50 \mathrm{ppm}$ & $5,25 \pm 1,0^{\mathrm{f}}$ & $17,21 \pm 0,13^{\mathrm{e}}$ & $20,22 \pm 0,13^{\mathrm{d}}$ & $23,99 \pm 0,21^{\mathrm{c}}$ & $25,34 \pm 0,13^{\mathrm{b}}$ & $29,15 \pm 0,13^{\mathrm{a}}$ \\
$100 \mathrm{ppm}$ & $9,86 \pm 0,7^{\mathrm{f}}$ & $26,75 \pm 0.12^{\mathrm{e}}$ & $31,98 \pm 1,7^{\mathrm{d}}$ & $34,33 \pm 0,13^{\mathrm{c}}$ & $36,59 \pm 0,13^{\mathrm{b}}$ & $39,45 \pm 0,2^{\mathrm{a}}$ \\
$150 \mathrm{ppm}$ & $21,40 \pm 4,6^{\mathrm{d}}$ & $33,17 \pm 0,13^{\mathrm{c}}$ & $36,20 \pm 0,22^{\mathrm{cb}}$ & $38,46 \pm 0,13^{\mathrm{b}}$ & $39,42 \pm 0,17^{\mathrm{b}}$ & $41,51 \pm 0,2^{\mathrm{a}}$ \\
$200 \mathrm{ppm}$ & $31,7 \pm 1,8^{\mathrm{e}}$ & $41,90 \pm 0,08^{\mathrm{f}}$ & $45,15 \pm 0,26^{\mathrm{c}}$ & $50,58 \pm 0,1^{\mathrm{d}}$ & $54,27 \pm 0,13^{\mathrm{b}}$ & $57,38 \pm 0,13^{\mathrm{a}}$ \\
$250 \mathrm{ppm}$ & $42,78 \pm 2,4^{\mathrm{e}}$ & $50,96 \pm 0,13^{\mathrm{d}}$ & $51,62 \pm 0,5^{\mathrm{d}}$ & $61,57 \pm 0,2^{\mathrm{c}}$ & $56,42 \pm 0,21^{\mathrm{b}}$ & $58,21 \pm 0,13^{\mathrm{a}}$ \\
\hline
\end{tabular}

Keterangan: Huruf superskrip yang berbeda pada baris yang sama menunjukkan ada perbedaan nyata antar perlakuan $(p<0,05), \mathrm{n}=3$

Suhu pemanasan berpengaruh sangat nyata terhadap uji RSA-DPPH ETP $(p<0,05)$. Peningkatan suhu pemanasan (dry-thermal) pada oven $\left(30-120^{\circ} \mathrm{C} / 3\right.$ menit) pada semua konsentrasi (50-250 ppm) ETP mampu meningkatan aktivitas penangkapan radikal bebas. Pada konsentrasi rendah (50 ppm) aktivitas penangkapan radikal 
bebas naik dari $5,25 \pm 1,0 \%\left(30^{\circ} \mathrm{C}\right)$ menjadi $29,15 \pm 0,13 \% \quad\left(120^{\circ} \mathrm{C}\right)$ naik $450 \%$, pada konsentrasi tinggi (250 ppm) aktivitas penangkapan radikal bebas naik dari $42,78 \pm 2,4 \%\left(30^{\circ} \mathrm{C}\right)$ menjadi $58,21 \pm 0,13 \%$ $\left(120^{\circ} \mathrm{C}\right)$ naik $36 \%$. Hal ini serupa dengan penelitian Wu et al. (2013) bahwa proses sangrai (roasting) $\left(150^{\circ} \mathrm{C} / 60\right.$ menit) pada biji sorghum pada proses pembuatan teh sorghum (sorghum tea) secara signifikan mampu meningkatan kadar asam fenolik, total fenolik, total flavonoid dan procyanidin (PAC) serta korelatif dengan uji penangkapan radikal bebas DPPH (RSA-DPPH). Namun demikian mekanisme peningkatannya belum sepenuhnya diketahui ( $\mathrm{Wu}$ et al., 2013; Taylor dan Duodu, 2019).

Pada penelitian sebelumnya menunjukkan bahwa peningkatan suhu (60$90^{\circ} \mathrm{C}$ ) dan lama waktu (2-10 menit) seduh teh Putih korelatif dengan peningkatan aktivitas antioksidan seduhan yang dihasilkan (Rohadi et al., 2018). Uji total fenolik, total flavonoid, dan aktivitas penangkapan radikal bebas DPPH serta daya reduksi ion $\mathrm{Fe}^{3+}$ ETP menunjukkan peningkatan seiring dengan peningkatan suhu pengovenan. Nilai $I_{50}$
ETP juga meningkat (320-182,5 ppm) seiring dengan peningkatan suhu pengovenan $\left(30-120^{\circ} \mathrm{C}\right)$, namun demikian koefisien korelasinya $(r)$ semakin rendah $\left(30-120^{\circ} \mathrm{C}\right), r$ $=0,97-0.45$ (Tabel 5). Artinya semakin tinggi suhu proses pangan maka peningkatan konsentrasi ETP yang ditambahkan, tidak banyak berpengaruh terhadap peningkatan aktivitas penangkapan radikal bebas (Tabel 4). Aktivitas antioksidan aqueous ETP termasuk lemah dibanding antioksidan sintetis BHA dan ekstrak biji anggur (grape seed extract) (Rohadi dan Wahjuningsih, 2018).

Pada awal pembahasan disebutkan bahwa peningkatan suhu pemanasan dalam oven mampu meningkatkan nilai baik total fenolik, total flavonoid, dan aktivitas penangkapan radikal bebas. Terdapat korelasi yang positif antara kenaikan total fenolik dan flavonoid dengan aktivitas penangkapan radikal bebas. Hal ini sejalan dengan hasil-hasil penelitian terpublikasi sebelumnya pada teh putih (Rohadi dan Wahjuningsih, 2018; Rohadi et al., 2018) dan sifat antioksidatif ekstrak biji Duwet (Rohadi et al., 2016).

Tabel 5. Nilai IC ${ }_{50}$ ETP pada berbagai suhu pemanasan (ppm)

\begin{tabular}{cccc}
\hline Perlakuan & Persamaan regresi & $\mathrm{IC}_{50}$ & $r$ \\
\hline $30^{\circ} \mathrm{C}$ & $\mathrm{y}=0,156 \mathrm{x}$ & 320 & 0,97 \\
$80^{\circ} \mathrm{C}$ & $\mathrm{y}=0,216 \mathrm{x}$ & 231 & 0,94 \\
$90^{\circ} \mathrm{C}$ & $\mathrm{y}=0,229 \mathrm{x}$ & 218,34 & 0,83 \\
$100^{\circ} \mathrm{C}$ & $\mathrm{y}=0,261 \mathrm{x}$ & 191,57 & 0,87 \\
$110^{\circ} \mathrm{C}$ & $\mathrm{y}=0,260 \mathrm{x}$ & 192 & 0,70 \\
$120^{\circ} \mathrm{C}$ & $\mathrm{y}=0,274 \mathrm{x}$ & 182 & 0,45 \\
\hline
\end{tabular}

Ket.: $I_{50}$, konsentrasi (ppm) untuk scavenging $50 \%$ radikal bebas

\section{Hasil Analisis Daya Reduksi ETP}

Hasil analisis aktivitas total reduksi (FRAP) ETP pada berbagai suhu pemanasan disajikan pada Tabel 5. Suhu pemanasan berpengaruh sangat nyata terhadap uji reduksi total ETP $(p<0,05)$. Peningkatan suhu pemanasan (dry-thermal) pada microwave oven $\left(30-120^{\circ} \mathrm{C} / 3\right.$ menit) pada semua konsentrasi (50-250 ppm) ETP mampu meningkatan aktivitas mereduksi ETP. Uji reduksi (kemampuan) mereduksi ion feri $\left(\mathrm{Fe}^{3+}\right)$ menjadi fero $\left(\mathrm{Fe}^{2+}\right)$ dipakai sebagai salah satu parameter aktivitas antioksidan (Brewer, 2011). Ion feri dan ion logam jenis lain diketahui sebagai logam oksidator yang kuat pemicu (trigger) peristiwa oksidasi. 
Keberadaan oksidator ion logam ini harus dilemahkan (direduksi). Senyawa yang memiliki kemampuan mereduksi ion logam antara lain senyawa polifenol yang terdapat pada ETP.

Hasil uji FRAP sampel menunjukkan bahwa ETP memiliki kemampuan mereduksi yang semakin meningkat pasca pemanasan dalam oven, yang ditunjukkan dengan nilai absorbansi (optical density) pada $\lambda=700 \mathrm{~nm}$ yang semakin meningkat dari 0,046 (50 ppm $/ 30^{\circ} \mathrm{C}$ ) menjadi 0,091 (50 $\left.\mathrm{ppm} / 120^{\circ} \mathrm{C}\right)$ hingga $0,28\left(250 \mathrm{ppm} / 30^{\circ} \mathrm{C}\right)$ menjadi $0,662\left(250 \mathrm{ppm} / 120^{\circ} \mathrm{C}\right)$. Semakin tinggi suhu pemanasan $\left(30-120^{\circ} \mathrm{C}\right)$ korelatif dengan peningkatan daya mereduksi ETP.
Peningkatan daya mereduksi ETP akibat pemanasan (dry-thermal) korelatif dengan uji total fenolik, total flavonoid dan uji RSADPPH. Hal ini sesuai hasil penelitian, Wu et al. (2013) yang menyatakan bahwa sangrai (roasting) $\left(150^{\circ} \mathrm{C} / 60\right.$ menit) pada biji sorghum secara signifikan mampu meningkatan kadar asam fenolik, total fenolik, total flavonoid dan procyanidin (PAC) serta korelatif dengan uji penangkapan radikal bebas DPPH (RSADPPH) dan uji total reduksi. Namun menurut Chamorro et al. (2012) pemanasan dengan autoclave dan oven pada ekstrak biji anggur maupun grape pomace tidak secara nyata meningkatkan sifat antioksidatifnya.

Tabel 6. Hasil analisis FRAP ETP pada berbagai suhu (OD)

\begin{tabular}{|c|c|c|c|c|c|c|}
\hline \multirow{2}{*}{ [Kons.] } & \multicolumn{6}{|c|}{ Suhu $\left({ }^{\circ} \mathrm{C}\right)$} \\
\hline & 30 & 80 & 90 & 100 & 110 & 120 \\
\hline 50 ppm & $0,046 \pm 0,005^{d}$ & $0,063 \pm 0,002^{c}$ & $0,077 \pm 0,003^{b}$ & $0,081 \pm 0,004^{b}$ & $0,082 \pm 0,003^{b}$ & $0,091 \pm 0,004^{a}$ \\
\hline 100 ppm & $0,076 \pm 0,009 e$ & $0,134 \pm 0,002^{d}$ & $0,145 \pm 0,003^{c}$ & $0,186 \pm 0,003^{b}$ & $0,192 \pm 0,003^{b}$ & $0,202 \pm 0,003^{a}$ \\
\hline 150 ppm & $0,102 \pm 0,01^{e}$ & $0,3 \pm 0,003^{d}$ & $0,312 \pm 0,003^{c}$ & $0,317 \pm 0,003^{c}$ & $0,33 \pm 0,04^{b}$ & $0,342 \pm 0,003^{a}$ \\
\hline 200 ppm & $0,15 \pm 0,02^{\mathrm{e}}$ & $0,395 \pm 0,003^{d}$ & $0,481 \pm 0,003^{c}$ & $0,482 \pm 0,003^{c}$ & $0,513 \pm 0,003^{b}$ & $0,538 \pm 0,003^{a}$ \\
\hline 250 ppm & $0,283 \pm 0,05^{c}$ & $0,612 \pm 0,003^{b}$ & $0,632 \pm 0,003^{\text {ba }}$ & $0,642 \pm 0,003^{\mathrm{ba}}$ & $0,652 \pm 0,003^{\text {ba }}$ & $0,662 \pm 0,003^{a}$ \\
\hline
\end{tabular}

Keterangan: Huruf superskrip yang berbeda pada baris yang sama menunjukkan ada perbedaan nyata antar perlakuan $(p<0,05), \mathrm{n}=3$.

Diduga fenomenaini, yakni peningkatan suhu pemanasan $\left(30-120^{\circ} \mathrm{C}\right)$ korelatif dengan peningkatan uji total fenolik, total flavonoid, aktivitas penangkapan radikal bebas DPPH dan daya mereduksi ETP disebabkan meningkatnya konsentrasi senyawa bioaktif yang memiliki aktivitas antioksidan melalui mekanisme hidrolisis. Namun demikian belum jelas (clear) tentang hal tersebut. Kuat diduga peningkatan hasil uji total fenolik, total flavonoid dan aktivitas antioksidan ETP yang dipanaskan oven disebabkan peristiwa degradasi panas dan hidrolisis menjadi senyawa fenolik sederhana.

\section{SIMPULAN}

Stabilitas sifat antioksidan ekstrak teh Putih (ETP) meningkat seiring dengan peningkatan suhu pemanasan dalam oven $\left(30-120^{\circ} \mathrm{C}\right)$ selama 3 menit. Pemanasan mampu meningkatkan hasil uji total fenolik, total flavonoid, aktivitas penangkapan radikal bebas DPPH dan uji daya reduksi total serta meningkatkan nilai IC50 (320-182,5 ppm).

\section{Saran}

Diperlukan penelitian lanjut untuk mengelaborasi mekanisme peningkatan kapasitas antioksidatif ETP selama pemanasan dengan oven.

\section{DAFTAR PUSTAKA}

1. Brewer, M.S. 2011. Natural Antioxidant: Source, Compounds, Mechanisms of Action, and Potential Application. Comprehensive Reviews. Food Science and Food Safety, 10: 221247. 
2. Chamorro, S., Goñl, I., Viveros, A., Hervert-Hernandez, D., dan Brenes, A., 2012. Changes in polyphenolic content and antioxidant activity after thermal treatments of grape seed extract and grape pomace. European Food Research Technololy, 234 (1):147-155. DOI 10.1007/s00217011-1621-7.

3. Dewanto, V., Xianzhong Wu, Kafui K. Adom, dan Rui Hai Liu. 2002. Thermal Processing Enhances the Nutritional Value of Tomatoes by Increasing Total Antioxidant Activity. Journal of Agricultural and Food Chemistry, 50:3010-3014.

4. Ebrahimzadeh, M A., Pourmorad, F. dan Hafezi, S. 2008. Antioxidant activities of Iranian Corn Silk. Turk Journal Biology, 32: 43-49.

5. Hihat, S., Remini, H. dan Madani, K. 2017. Effect of oven and microwave drying on phenolic compounds and antioxidant capacity of coriander leaves. International Food Research Journal, 24(2): 503-509.

6. Hilal, Y dan Engelhardt, U. 2007. Characterisation of white tea-Comparison to green and black tea. Journal of Verbr. Lebensm. 2: 414 - 421.

7. Hithamani, G., dan Srinivasan, K. 2014. Effect of domestic processing on the polyphenol contentand bioaccessibility in finger millet (Eleusine coracana) and pearl millet (Pennisetum glaucum). Food Chemistry, 164:55-62. DOI: 10.1016/j.foodchem.2014.04.107.

8. Khanbabaee, K. dan Teunis van Ree. 2001. Tannin, Classifikation and Definition. Nat. Prod. Rep., 18: 641-649. DOI: 10.1039/b101061l.

9. Lelita, D.I. 2018. Sifat Antioksidatif Ekstrak Teh (Camellia sinensis Linn.) Jenis Teh Hijau, Teh Hitam, Teh Oolong dan Teh Putih Dengan Pengeringan Beku (Freez Drying). Skripsi, Jurusan Teknologi Hasil Pertanian, Fakultas Teknologi Pertanian, Universitas Semarang, Semarang.
10. Li-Yuan Zhou, Wan Li, Wen-Juan Pan, Sajid Hussain, Ya Wang, Wen-Qiang Guo, Zheng-Nan Cai, Wei-Wei Yang, Dan-Dan-Wang dan Yan Chen. 2017. Effects of thermal processing on nutritional characteristics and non-volatile flavor components from Tricholoma lobayense. Emirates Journal of Food and Agriculture, 29(4): 285-292. DOI. 10.9755/ejfa.2016-121815.

11. Martin, S., Solange I. Mussatto, G., Martinez-Avila, J., Montanes-Saenz, C.N. Aguilar dan Jose A. Teixeira. 2011. Bioactive phenolic compounds: Production and extraction by solidstate fermentation. A review. Journal Biotechnology Advances, 29:365-373.

12. Micali, M. dan Fiorino, M. 2016. Thermal Processing in Food Industries and Chemical Transformation. Dalam Micali, M. (ed.). (2016). The Chemistry of Thermal Food Processing Procedures, Chemistry of Foods. DOI 10.1007/978-3-319-42463-7_2.

13. Mielnik, M.B., Olsen, E., Vogt, G., Adeline, D. dan Skrede, G. 2006. Grape seed extract as antioxidant in cooked, cold storage turkey meat. Elsevier, LWT 39:191-198.

14. Rai, N., Jigisha, A., Navin, K., Pankaj, G. 2012. Green tea a magical herb with miraculous outmes. Int. Research Journal of Pharmacy, 3(5):139-148.

15. Reda, S.Y. 2011. Evaluation of Antioxidants Stability by Thermal Analysis and Its Effect in Heated Edible Vegetable Oil. Ciência e Tecnologia de Alimentos, 31(2): 475480.

16. Rohadi, Fonda Natalia, Diyan Widyantika dan Ery Pratiwi. 2018. Metode Penyeduhan Dan Aktivitas Antioksidatif Minuman Teh (C. sinensis Linn.) Jenis Teh Putih Yang Dihasilkan. Inisiasi, 7(2):241-249.

17. Rohadi, Santoso, U., Raharjo, S., Falah, I.I. 2016. Aktivitas antioksidan ekstrak biji Duwet (Syzygium cumini Linn.) 
pada peroksidasi lipida secara in vitro. Jurnal Agritech, 36(1): 30-37. DOI: 10.22146/agritech.10681.

18. Rohadi dan Wahjuningsih, S.B. 2018. Komparasi Aktivitas Antioksidatif Ekstrak Teh Putih (C. sinensis Linn.) Dibandingkan Ekstrak Biji Anggur dan BHA pada Berbagai Konsentrasi. J. Aplikasi dan Teknologi Pangan, 7(2).62-67.

19. Setyopratomo, P. 2014. Extraction of Phenolic Compounds from Green Tea Using Ethanol. ARPN J. of Engineering and Applied Sciences, 9(9):1516-1521.

20. Taylor, J. R.N dan Kwaku G. Duodu. 2019. Sorghum and Millets. Chemistry, Technologi and Nutritional Attributes. $2^{\text {nd }}$. Ed. Cambridge, UK: Elsevier Inc.

21. Tram, N.N., Hien, P.P., Oanh, H.N. 2015. Optimizing the extraction conditions of phenolic compounds from fresh tea shoot. Journal of Food and Nutrition Sciences,3(1-2): 106-110. DOI: 10.11648/j.jfns.s.2015030102.30

22. Vasi, S., dan Austin, A. 2009. Antioxidants Potential of Eugenia jambolana Lam. Seeds. Journal of Biological Sciences, 9(8):894-898.
23. Vayupharap, B. dan Laksanalamal, V. (2012). Recovery of Antioxidant from Grape Seeds and its Application in Fried Food. Journal Food Process Technology 3(4):1-6.

24. Widyasanti, A., Rohdiana, D. dan Ekatama, N. 2016. Aktivitas Antioksidan Ekstrak The Putih (C. sinensis) Dengan Metode DPPH (2,2 diphenyl, 1-picrylhydracil), Fortech, 1 (1):1-9.

25. Wu, Li., Zhaohui Huang, Peiyou Qin dan Guixing Ren. 2013. Effects of processing on phytochemical profiles and biological activities for production of sorghum tea. Food Research International, 53(2): 678-685.

26. Yoshida,H. dan Takagi, S.,(1997). Effects of Seed Roasting Temperature and Time on The Quality Characteristics of Sesame (Sesamum indicum) Oil. Journal of the Science of Food and Agricultural, 75(1):19-26.

27. Zhang, L.L., dan Lin, Y.M. (2009). Antioxidant tannins from Syzygium cumini fruit. African Journal of Biotechnology, 8(10):2301-2309. 